Hubungan Pengobatan Antiretroviral ...... (Mina Blandina Ayomi)

\title{
Hubungan Pengobatan Antiretroviral dengan Stres pada Orang Dengan HIV/AIDS Di Rumah Singgah X Kota Jayapura Tahun 2016
}

\section{Mina Blandina Ayomi *)}

*) Program Studi Ilmu Kesehatan Masyarakat Fakultas Kesehatan Masyarakat Univrsitas Cenderawasih Jayapura Korespondensi : minaayomi@gmail.com

\begin{abstract}
ABSTRAK
Stres yang terjadi pada individu akan berdampak pada munculnya masalah yang berhubungan dengan kesehatan, psikologi dan interaksi interpersonal. Pada gangguan fisik seseorang mengalami stres akan mudah terserang penyakit, pada gangguan mental stres berkepanjangan akan mengakibatkan ketegangan, hal ini akan merusak tubuh dan gangguan kesehatan. Pada gangguan interpersonal stres akan lebih sensitif terhadap hilangnya percaya diri, menarik diri dan lain-lain. Dukungan yang didapatkan oleh ODHA dapat dijadikan sebagai koping atau upaya untuk mempertahankan hidupnya, karena penyakit HIV/ AIDS bukan akhir dari segalanya, dengan koping yang baik yang dimiliki oleh ODHA akan sangat membantu dalam kepatuhan pengobatan ARV dan meneruskan hidupnya.

Jenis penelitian yang digunakan adalah Explanatory Research, Waktu penelitian akan dilakukan pada bulan September Tahun 2016 dan lokasi penelitian tersebut dilakukan empat rumah singgah Surya Kasih Kota Jayapura. Sampel dalam penelitian ini ada 33 respoden. Cara yang digunakan dalam pengambilan data pada penelitian ini adalah dengan menggunakan kuisioner yang pengisian dilakukan oleh responden.

Hasil penelitian menunjukkan bahwa umur 27-30 tahun 11 responden (31,3\%), jenis kelamin laki-laki 18 responden (54,5\%), cara penularan melalui hubungan seks 28 responden (84,8\%), pengobatan ARV minum 31 responden (93,9\%), ada hubungan antara pengobatan ARV dengan stres pada orang dengan HIV AIDS di rumah singgah Kota Jayapura dengan nilai p-value 0,001.
\end{abstract}

Kata Kunci: Pengobatan ARV, Stres, Orang Dengan HIV/AIDS

Antiretroviral Treatment Relationships with Stress on People Living with HIV / AIDS In Houses $\boldsymbol{X}$ Jayapura City $\boldsymbol{X}$ Year 2016. Stress that occurs in individuals will impact on the emergence of problems related to health, psychology and interpersonal interaction. In a physical disorder a person experiencing stress will be susceptible to disease, the mental disorders of prolonged stress will cause tension, it will damage the body and health problems. In interpersonal disorders stress will be more sensitive to loss of self-confidence, withdrawal and others. The support gained by PLWHA can be used as a coping or survival effort, as HIV I AIDS is not the end of everything, with good coping owned by PLWHA will be very helpful in antiretroviral treatment adherence and continue its life.

The type of research used is Explanatory Research, The time of the research will be done in September Year 2016 and the location of the research was conducted four shelters Surya 
Kasih Kota Jayapura. The sample in this research there are 33 responder. The way used in data retrieval in this study is to use questionnaires that are filled by respondents.

The results showed that the age of 27-30 years 11 respondents (31.3\%), male gender 18 respondents (54.5\%), mode of transmission through sex 28 respondents (84.8\%), ARV treatment drink 31 of respondents (93.9\%), there is a relationship between ARV treatment with stress in people with HIV AIDS in Jayapura shelter home with p-value value 0.001.

Keywords: ARV Treatment, Stress, People With HIV / AIDS

\section{PENDAHULUAN}

Stres yang terjadi pada individu akan berdampak pada munculnya masalah yang berhubungan dengan kesehatan, psikologi dan interaksi interpersonal. Pada gangguan fisik seseorang mengalami stres akan mudah terserang penyakit, pada gangguan mental stres berkepanjangan akan mengakibatkan ketegangan, hal ini akan merusak tubuh dan gangguan kesehatan. Pada gangguan interpersonal stres akan lebih sensitif terhadap hilangnya percaya diri, menarik diri dan lain-lain(Anaroga, 2001).

\section{AIDS (Acquired Immunodeficiency} Syndrome) dapat diartikan sebagai kumpulan gejala atau penyakit yang disebabkan oleh menurunnya kekebalan tubuh akibat infeksi oleh virus HIV (Human Immunodeficiency Virus) yang termasuk famili retroviridae. Penularan HIV/AIDS terjadi akibat melalui cairan tubuh yang mengandung virus HIV yaitu melalui hubungan seksual, baik homoseksual maupun heteroseksual, jarum suntik pada pengguna narkotika, transfusi komponen darah dan dari ibu yang terinfeksi HIV ke bayi yang dilahirkannya. Secara klinis, seseorang didefinisikan mengidap AIDS jika hitungan sel $\mathrm{CD}^{+}$limfosit $\mathrm{T}$ $<200 / \mathrm{mm}^{3}$ atau dibawah $14 \%$ atau jika terkena satu macam atau lebih infeksi opurtunistik (UNICEF, 2013)

\section{Menurut WHO (Word Health} Organitation) tahun 2013 tercatat 70 juta kasus HIV/AIDS dengan 35,3 juta orang menderita HIV positif, 33 juta orang pada tahap AIDS. Namun, sekitar $90 \%$ dari populasi ODHA (Orang Dengan HIV/AIDS) dunia berada di negara-negara berkembang. Indonesia termasuk negara dengan laju penularan tertinggi di wilayah ini (WHO,2013)

Data Kementrian Kesehatan hingga september 2014, jumlah kumulatif HIV dan AIDS di Papua masing - masing 16.051 dan 10.184 kasus. Sedangkan data Komisi 
Penanggulangan AIDS Nasional minum obat ARV ( Dinkes Propinsi Papua, menyebutkan prevalensi penularan HIV 2013)

AIDS di Papua turun menjadi 2,3 persen pada 2013 dari pendataan terakhir 2007 yang mencapai 2,4 persen. Data Dinas Kesehatan Provinsi Papua menyebutkan kasus HIV/ AIDS di wilayah Papua sekarang ini mencapai 19.202 kasus (dimana kasus HIV sebanyak 7.318 dan 11.884 kasus AIDS) pada 31 Desember 2014.

Kabupaten/Kota di Papua menunjukan bahwa Kabupaten Mimika menempati kasus tertinggi yaitu 3.921 kasus, kemudian diikuti oleh Kabupaten Nabire yaitu 3.760 kasus, dan Kota Jayapura yaitu 3.279 kasus, kemudian Kabupaten Merauke yaitu 1.647 kasus. Sejarah penularan HIV/AIDS di Papua dilaporkan pertama kali terjadi di Kabupaten Merauke tahun 1992. Namun, hingga saat ini HIV/AIDS telah menyebar ke seluruh wilayah Papua. Kota Jayapura menempati urutan ketiga dengan jumlah kasus 3.279 kasus. Kumulatif Pasien HIV/AIDS di Kota Jayapura yang menjalani pengobatan ARV dilaporkan pada Tahun 2012 - 2014 yang pernah melakukan terapi sebanyak 1.187 orang menurun menjadi 572 orang yang masih dalam terapi ARV hal ini memungkinkan bahwa masih banyak ODHA yang belum patuh terhadap pengobatan 
Kasus HIV/AIDS yang terus meningkat setiap tahunnya, dan menyerang kaum wainta, dan terlebih pada usia produktif yang membutuhkan perhatian khusus dari semua pihak, termasuk intansi Pendidikan yang menghasilkan tenaga kesehatan, agar kelak mereka bisa mengabdikan diri mereka untuk, melayani setiap orang yang membutuhkan termasuk ODHA, Dengan penyakit yang mereka derita sudah membuat mereka terpuruk, tertekan secara psikologis ditambah dengan penurunan berat badan. Hal-hal inilah yang membuat setiap ODHA menjadi malu untuk berusaha keluar dari masalah mereka, dan dengan mengatahui tekanan yang mereka hadapi, kami bisa membantu ODHA untuk keluar dari tekanan tersebut. Berdasarkan uraian diatas maka peneliti perlu melakukan penelitian tentang factor-faktor yang berhubungan dengan stres pada orang dengan HIV/ AIDS di rumah singgah X di Kota Jayapura. Adapun tujuan penelitian ini adalah mengetahui hubungan pengobatan $A R V$ dengan stres pada orang dengan HIV/AIDS di rumah singgah X Kota Jayapura.

\section{METODE PENELITIAN}

Jenis penelitian ini adalah pengobatan $A R V$, pada orang dengan Explanatory Research yaitu penelitian HIV/AIDS di rumah singgah $\mathrm{X}$ Kota penjelasan dengan melakukan uji hubungan Jayapura. Lokasi penelitian akan dilakukan antara berbagai variabel, setelah itu dilihat besarnya pengaruh. Peneliti melakukan pengambilan sampel terpilih dalam suatu populasi dengan pendekatan cross sectional sutu penelitian untuk mempelajari dinamika korelasi antara faktor-faktor risiko dengan efek, dengan cara pendekatan, observasi atau pengumpulan data sekaligus pada suatu saat (point time approach) (Notoadmojo, 2010). di empat rumah singgah X Kota Jayapura. Pada bulan Juli sampai dengan September Tahun 2016. Sampel adalah objek yang diteliti dan dianggap mewakili seluruh populasi. Sampel dalam penelitian ini menggunakan metode Purposive Sampling yaitu metode yang ditentukan oleh peneliti berdasarkan pertimbangan tertentu. Adapun kriteria inklusi yaitu 1) ODHA yang tinggal Penelitian ini dilakukan dengan metode di rumah singgah di kota Jayapura, 2) ODHA kuantitatif, dimana akan diukur faktor umur, yang bersedia menjadi responden dengan jenis kelamin, perkawinan, cara penularan, menandatangani infom consent. Sedangkan 
kriteria eksklusi adalah: ODHA yang tidak dikumpulkan untuk dilakukan tinggal di rumah singgah dan ODHA yang pemeriksaan/validasi data, pengkodean tidak bersedia menjadi responden, sampel rekapitulasi dan tabulasi, kemudian yang digunakan sebanyak 33 orang dilakukan análisis statistik dengan responden. menggunakan program statistik. Adapun Cara yang digunakan dalam pengambilan rancangan analisa statistik yang akan data pada penelitian ini adalah dengan digunakan adalah análisis univariat dan menggunakan kuisioner yang pengisian bivariat.

dilakukan oleh peneliti. Data yang diperoleh

\section{HASIL PENELITIAN}

\section{Karakteritik Responden}

Berdasarkan data yang didapatkan, diketahui bahwa responden sebagian besar berjenis kelamin laki-laki (54,5\%). Menurut distribusi umur, diketahui responden sebagian besar

berusia $\geq 31$ tahun yaitu sebesar 45,5\%, 27-30 tahun sebanyak 33,3\% dan $<27$ tahun sebanyak 21,2\%. Berdasarkan status perkawinan, sebagian besar responden berstatus janda/duda $(69,6 \%)$ dan masingmasing sebanyak $15,2 \%$ berstatus menikah dan belum menikah.

\section{Cara Penularan}

Tabel 1 Distribusi Responden berdasarkan cara penularan pada orang dengan HIV/AIDS dirumah singgah X Kota Jayapura 2016

\begin{tabular}{cccc}
\hline No & Cara Penularan & Jumlah & Persen $(\%)$ \\
\hline 1 & Hubungan Seks & 28 & 84,8 \\
2 & Jarum Suntik & 5 & 15,2 \\
\hline & Total & 33 & 100 \\
\hline
\end{tabular}

\section{Pengobatan ARV}

Tabel 2. Distribusi Responden berdasarkan pengobatan $A R V$ pada orang dengan HIV/AIDS dirumah singgah X Kota Jayapura 2016

\begin{tabular}{cccc}
\hline No & Pengobatan $A R V$ & Jumlah & Persen (\%) \\
\hline 1 & Tidak minum obat & 2 & 6,1 \\
2 & Minum obat & 31 & 93,9 \\
\hline & Total & 33 & 100 \\
\hline
\end{tabular}




\section{Hubungan Antar Variabel}

Tabel 3. Hubungan Antara pengobatan ARV Dengan stres pada orang dengan HIV/AIDS dirumah singgah X Kota Jayapura tahun 2016

\begin{tabular}{|c|c|c|c|c|c|c|c|c|c|c|}
\hline \multirow{3}{*}{ No } & \multirow{3}{*}{$\begin{array}{c}\text { Pengobatan } \\
\text { ARV }\end{array}$} & \multicolumn{4}{|c|}{ Tingkat Stres } & \multirow{2}{*}{\multicolumn{2}{|c|}{ Total }} & \multirow{3}{*}{$\begin{array}{c}p- \\
\text { value }\end{array}$} & \multicolumn{2}{|c|}{$\begin{array}{c}C I \\
(95 \%)\end{array}$} \\
\hline & & \multicolumn{2}{|c|}{ Sedang } & \multicolumn{2}{|c|}{ Berat } & & & & Lower & Upper \\
\hline & & $\mathrm{n}$ & $\%$ & $\mathrm{n}$ & $\%$ & $\mathrm{~N}$ & $\%$ & & & \\
\hline 1. & $\begin{array}{l}\text { Tidak } \\
\text { Minum }\end{array}$ & 1 & 50 & 1 & 50 & 2 & 100 & \multirow{3}{*}{0.001} & & \\
\hline & Minum & 7 & 22,5 & 24 & 77,5 & 31 & 100 & & 0.189 & 62116 \\
\hline & Total & 8 & 24,2 & 25 & 75,8 & 33 & 100 & & & \\
\hline
\end{tabular}

\section{PEMBAHASAN}

Penelitian ini menguji hubungan terjadi apabila individu mengalami sejumlah pengobatan $A R V$ dengan stres pada orang tuntutan yang semakin meningkat atau dengan HIV/AIDS. Temuan dalam penelitian ini menunjukkan bahwa ada hubungan mengancam sehingga individu tersebut pengobatan ARV dengan sters pada ODHA. menilai bahwa dirinya tidak mampu Stres adalah suatu respon adaptif, melalui karakteistik individu dan atau proses menghadapi dan mengatasinya.(Vokic, 2007) psikologis secara langsung terhadap tindakan, situasi dan kejadian eksternal yang menimbulkan tuntutan khusus baik fisik maupun psikologis individu yang bersangkutan. Pendapat lain mengatakan bahwa stres adalah tanggapan yang menyeluruh dari tubuh terhadap tuntutan yang datang kepadanya.(Agung 2012 dan Anaroga, 2001)

Stres yang menyebabkan seseorang rentan terhadap sakit karena energinya terkuras akibat kelelahan secara fisik dan emosinya disebut sebagai distress. Distress Reaksi tubuh terhadap stressor pada seseorang sangat bervariasi dan berbeda dari masing-masing orang yang menerimanya. Perbedaan reaksi tersebut disebabkan oleh beberapa faktor antara lain: faktor psikologis yaitu Stres biasanya merupakan perasaan subyektif seseorang sebagai bentuk kelelahan, kegelisahan (anxiety) dan depresi. Reaksi psikologis akibat stres dapat dievaluasi dalam bentuk beban mental, kelelahan dan perilaku (arousal). Faktor sosial-budaya seseorang yaitu Setelah beberapa lama mengalami kegelisahan, depresi konflik dan stres di tempat kerja, maka pengaruhnya akan dibawa kedalam 
lingkungan keluarga dan lingkungan social (Pallesen, 2007). Respon stres kepada gangguan kesehatan atau reaksi fisiologis. Bila tubuh mengalami stres, maka akan terjadi perubahan fisiologis sebagai jawaban atas terjadinya stres. Adapun sistem didalam tubuh yang mengadakan respon adalah diperantarai oleh saraf otonom, hypothalamic-pituitari axis dan pengeluaran katekolamin yang akan mempengaruhi fungsi-fungsi organ didalam tubuh seperti sistem kardiovaskuler, sistem gastro intestinal dan gangguan penyakit lainnya. Respon individu. Pengeruhnya sangat tergantung dari sifat dan kepribadian seseorang. Dalam menghadapi stres, individu dengan kepribadian introvert akan beraksi lebih negatif dan menderita ketegangan lebih besar dibandingkan dengan mereka yang berkepribadian ekstrovert. Seseorang dengan kepribadian fleksibel atau luwes akan mengalami ketegangan yang lebih besar dalam suatu konflik, dibandingkan dengan mereka yang berkepribadian rigid.

Menurut model jaring-jaring sebabakibat (the web of causation), suatu penyakit tidak bergantung pada suatu sebab yang berdiri sendiri-sendiri, melainkan sebagai akibat dari serangkaian proses sebab-akibat. Dengan demikian timbulnya suatu penyakit dapat dicegah atau dihentikan dengan memotong mata rantai berbagai faktor (Widyanti, 2008)

Tingkat stres dalam menghadapi suatu penyakit yang berbahaya memang membutuhkan perhatian yang khusus. Orang yang sudah terinfeksi virus HIV, akan membuat dirinya berada dalam suatu tekanan yang sulit untuk bisa keluar dari tekanan tersebut.

Dalam penelitian ini karakteristik orang dengan HIV/AIDS yang didapatkan adalah usia yang produktif yang paling banyak menderita HIV/ AIDS, usia 27-30 tahun. Pada usia ini setiap individu akan berusaha untuk bisa menunjukkan dirinya dalam mencapai setiap keinginan dalam hidupnya. Keinginan untuk memperoleh Pendidikan dan mengejar karir serta membina hubungan dalam berumah tangga juga akan ada pada usia ini, tanpa membedakan laki-laki maupun perempuan pada usia ini setiap orang pasti mengharapkan hal-hal yang ideal dan sempurna.

Laki-laki paling banyak yang menderita HIV/ AIDS dalam penelitian ini, laki-laki yang sudah mempunyai pekerjaan tetapi belum menikah akan menikmati hidupnya dengan bebas, dan akan ada pada tahap pencarian calon istri yang ideal, sehingga dengan mudah melakukan perilaku berisiko 
seperti melakukan hubungan seks sebelum ada dalam kehidupan pernikahan, istilah coba-coba juga terjadi didalam kehidupan mereka. Mencari yang terbaik tanpa berpikir, risiko yang dialaminya.

Perempuan Janda yang telah ditinggal suaminya karena meninggal juga menjadi yang lebih banyak dalam penelitian ini. Seorang wanita yang sudah mencapai usia produktif, bahkan hampir melewati masa dewasa menengah juga harus memikul beban sebagai seorang penderita HIV/AIDS, hanya karena tertular dari suaminya yang sering jajan diluar. Beban mental yang di rasakan oleh perempuan-perempuan dalam penelitian ini terkesan berat oleh peneliti, karena harus menjadi kepala keluarga dan harus mengurus anak-anak. Hal ini terjadi karena perempuan lebih sensitif terhadap keadaan yang tidak menyenangkan dan lebih tertutup untuk mengutarakan permasalahannya. Beberapa studi menunjukkan tingkat stres wanita lebih tinggi dari pada laki-laki didalam berbagai kelompok pekerjaan. Namun demikian tidak semua studi wanita lebih dalam penelitiannya telah menunjukkan bahwa kaum perempuan mengalami tingkatan stres yang lebih tinggi dibandingkan laki-laki. McDonough dan Walters menemukan bahwa perempuan cenderung merasa lebih stres dari tinggi stresnya. (Vokic, 2007)
Cara penularan HIV/AIDS lewat hubungan seks menjadi yang terbanyak dibandingkan dengan penggunaan jarum suntik, hubungan seks yang tanpa pengaman ini yang kemudian menjadi penyebab penularan. Virus HIV sebagai fenomena gunung es yang masih terselebung, membuat manusia tidak dapat mengetahui apakah setiap orang yang sehat secara fisik adalah mereka yang sehat.

Transmisi HIV secara seksual terjadi ketika ada kontak antara sekresi cairan vagina atau cairan preseminal seseorang dengan rectum, alat kelamin atau membrane mukosa mulut pasangnnya. Hubungan seksual reseptif tanpa pelindung lebih lebih berisiko daripada hubungan seksual insertif tanpa pelindung, dan risiko seks anal lebih besar daripada risiko hubungan seks biasa dan seks oral. Kekerasan seksual secara umum meningkatkan risiko penularan HIV karena pelindung umumnya tidak digunakan dan sering terjadi trauma fisik terhadap rongga vagina yang meudahkan transmisi HIV( Budioro,2007)

Hubungan pengobatan ARV dengan Tingkat Stres

Terapi anti retro viral berarti mengobati infeksi HIV dengan obat-obatan. Obat tersebut (yang disebut ARV) tidak dapat 
membunuh virus. Meskipun demikian, obat tersebut dapat memperlambat pertumbuhan virus. Waktu pertumbuhan virus diperlambat, begitu juga HIV. Karena HIV adalah retrovirus, obat-obatan ini biasa disebut sebagai terapi anti retro viral (Widyanti,2008)

Pengobatan ARV yang dianjurkan WHO adalah kombinasi dari 3 obat ARV. Terdapat beberapa regimen yang dapat dipergunakan dengan keunggulan dan kerugiannya masing-masing. Kombinasi obat anti retro viral yang umumnya digunakan di Indonesia adalah kombinasi zidovudin (ZDV)/lamivudin (3TC), dengan nevirapin (NVP) (Poksidus, 2010) Anti retro viral biasanya ditawarkan jika viral load di atas 100.000, jumlah CD4 dibawah 350 atau ada gejala HIV seperti kandidiasis. Perlu diingat, bahwa keputusan ini adalah sangat penting dan sebaiknya dibahas terlebih dahulu dengan dokter. Salah satu hal yang perlu dipertimbangkan adalah efek samping yang mungkin dirasakan oleh pasien. Selain itu, pemantauan jumlah virus di dalam darah (viral load) secara teratur juga perlu dilakukan agar dapat dideteksi apakah sudah waktunya mengganti kombinasi obat ( Poksidus, 2010)
Efek samping yang paling sering terjadi adalah keluhan kembung, mual, diare yang sifatnya dapat terjadi sementara atau menetap. Efek samping yang lain adalah rasa lelah, dan sakit kepala yang disebabkan AZT dan mimpi buruk akibat efavirenz. Beberapa efek samping yang lain yang jarang terjadi namun serius adalah anemia karena AZT, neuropati perifer akibat $\mathrm{d} 4 \mathrm{~T}$, toksisitas retinoid karena $P I$ dan reaksi hipersensitivitas akibat penggunaan NNRTI (Poksidus, 2010)

Orang dengan HIV/AIDS yang mengalami stres berat lebih banyak yang masih tetap minum obat ARV, dalam mengalami stres berat dengan penyakit atau tekanan yang sedang dialami oleh ODHA, mereka tetap didampingi untuk tetap minum obat, karena Tujuan utama terapi ARV adalah penekanan secara maksimum dan berkelanjutan terhadap jumlah virus, pemulihan atau pemeliharaan fungsi imunologik, perbaikan kualitas hidup dan pengurangan morbiditas dan mortalitas HIV. Pemberian ARV telah menyebabkan kondisi kesehatan ODHA menjadi jauh lebih baik. Infeksi yang sebelumnya sukar diobati, menjadi jauh lebih mudah ditangani ( Widyanti, 2008). Model jaring-jaring sebabakibat (the web of causation), suatu penyakit tidak bergantung pada suatu sebab yang 
berdiri sendiri-sendiri, melainkan sebagai akibat dari serangkaian proses sebab-akibat. Dengan demikian timbulnya suatu penyakit dapat dicegah atau dihentikan dengan memotong mata rantai berbagai faktor (Budioro,2007)

Stres yang dialami oleh ODHA juga berhubungan secara signifikan, yang mana ODHA mempunyai tingkt stres yang berat, tetapi tetap minum obat ARV, hal ini menunjukkan bahwa, stres yang dialami mereka, tergolong dalam dalam stres jenis (Vokic, 2007) Eustress, yaitu hasil dari respon terhadap stres yang bersifat sehat, positif dan konstruktif (bersifat membangun). Hal tersebut termasuk kesejahteraan individu dan juga organisasi yang diasosiasikan dengan pertumbuhan, fleksibilitas, kemampuan adaptasi dan tingkat kinerja yang tinggi.

Berbeda dengan mereka yang mengalami stres sedang tetapi tidak minum obat, mereka tergolong dalam Distress, yaitu hasil dari respon terhadap stres yang bersifat tidak sehat, negatif, dan destruktif (bersifat merusak). Hal tersebut termasuk konsekuensi individu dan juga organisasi seperti penyakit jantung dan pembuluh darah, tingkat kehadiran (absensi) yang tinggi, yang berhubungan dengan keadaan sakit, penurunan kinerja dan kematian.
Menurut Bernard, stres yang menyebabkan seseorang rentan terhadap sakit karena energinya terkuras akibat kelelahan secara fisik dan emosinya disebut sebagai distress. Distress terjadi apabila individu mengalami sejumlah tuntutan yang semakin meningkat atau mengancam sehingga individu tersebut menilai bahwa dirinya tidak mampu menghadapi dan mengatasinya (Pourmahabadian, 2005).

\section{SIMPULAN}

Berdasarkan hasil penelitian dapat disimpulkan bahwa orang dengan HIV/AIDS di rumah singgah $\mathrm{X}$ di Kota Jayapura paling banyak umur 27-30 tahun 11 responden (31,3\%), Jenis kelamin laki-laki 18 responden ( $54,5 \%)$, Status perkawinan yang Janda 18 (54,5\%) paling banyak, Cara penularan melalui hubungan seks 28 responden $(84,8 \%)$ paling banyak, Pengobatan $A R V$ mempunyai hubungan dengan Stres pada orang dengan HIV AIIDS di rumah singgah X Kota Jayapura Tahun 2016

\section{KEPUSTAKAAN}

Agung. Stress Kerja (Pengertian dan Pengenalan). http:/agungpia.multiply.com/journal/ite $\mathrm{m} / 35$.

Stress_kerja_Pengertian_dan_Pengenala n diunduh 4 April 2012 
Anoraga,P. Psikologi Kerja. Rineka Cipta, Jakarta. 2001

Azam K, Pourmahabadian M, Rezaeian A, Work Related Stres Chracteristic on Correctional Staff Job Stress . Applied psychology in Criminal Justice.2005

B, Budioro, 2007. Pengantar Epidemiologi Edisi II. Badan Penerbit Universitas Diponegoro Semarang. Semarang

Dinas Kesehatan Provinsi Papua. Informasi HIV/AIDS Provinsi Papua Tahun 2013.

Kemenkes RI, 2014, . Laporan WHO tentang jumlah penderita HIV/ AIDS di Papua. Profil KPA Nasional. Jakarta

Komisi Penaggulangan AIDS (KPA) Provinsi Papua, 2014, Profil KPA Provinsi Papua, Kasus ODHA di Provinsi Papua Tahun 2014, Jayapura

Komisi Penaggulangan AIDS (KPA) Kota Jayapura, 2016, Profil KPA Provinsi Papua, Kasus ODHA di Kota Jayapura Tahun 2016, Jayapura

K. Widyanti, FPSI UI, 2008, Strategi Koping dalam manusia dan kehidupannya. Bandung.
Notoadmodjo Soekidjo. 2010. Metodologi Penelitian Kesehatan. Rineke Cipta: Jakarta,

Pallesen ES. Work-related Stres and Health among Hotel Employees in Malmo. Tesis. 2007

Pokdisus RSCM, 2010, Tata Laksana Pengobatan ARV pada pasien HIV/AIDS.

UNAIDS. Global Report: UNAIDS Report On The Global AIDS Epidemic. 2012. Diunduh pada tanggal 25 Oktober 2013

UNICEF Indonesia. Respon Terhadap HIV\& AIDS: Ringkasan Kajian: Jakarta, 2012. Diunduh pada tanggal 25 Oktober 2013.

Vokic NP, Bogdanic A. Individual Differences and occupational stress perceived, a Croatian survey.working paper series university of Zagreb.2007

WHO, 2013. Laporan WHO bulan Oktober 2013 tentang jumlah penderita HIV/ AIDS di dunia. WHO International. Diakses tanggal 29 Oktober 2014 